\title{
ANALISA BIBLIOMETRIK PUBLIKASI ILMIAH BERTEMA BIOREFINERI BIOMASSA BERLIGNOSELULOSA
}

\author{
Indah Hartati*, Sinta Ariyani, Hani Haswati, Habib Abdun Nafik, dan Dyah Yuliana Zulfa \\ Jurusan Teknik Kimia, Fakultas Teknik, Universitas Wahid Hasyim Semarang \\ Jl. Menoreh Tengah X/22 Sampangan, Gajah Mungkur Kota Semarang Jawa Tengah 50232 \\ *Email: hartatiprasetyo@gmail.com
}

\begin{abstract}
Abstrak
Keluasan spectrum potensi produk yang dapat dihasilkan dari proses biorefineri biomassa berlignoselulosa telah merupakan unsur pendorong utama berkembangnya penelitian serta publikasi ilmiah dengan topik biorefineri lignoselulosa. Artikel ini disusun dengan tujuan menganalisa bibliometri publikasi ilmiah dengan topik biorefineri biomassa berlignoselulosa yang diterbitkan pada berbagai jurnal yang terindeks scopus pada tahun 2000-2019. Analisa bibliometrik dilakukan menggunakan VOSviewer untuk menganalisa co-authorship berdasarkan nama penulis dan afiliasi penulis, serta analisa co-occurrence berdasar kata kunci. Hasil analisa bibliometrik ditampilkan menggunakan visualisasi jaringan, hamparan dan kerapatan. Hasil analisa bibliometrik terkait kekuatan tautan kolaborasi penulis berdasarkan afiliasinya, berdasar nama penulisnya serta kekuatan tautan kemunculan kata kunci pada publikasi publikasi ilmiah dengan topik biorefineri biomassa berlignoselulosa yang diterbitkan pada berbagai jurnal yang terindeks scopus pada tahun 2000-2019 disajikan dalam artikel ini. Hasil kajian menunjukkan jika kekuatan tautan kolaborasi penulis didominasi oleh kolaborasi antara penulis yang berafiliasi dari negara China dan Amerika. Hasil analisa bibliometri menggunakan VOSviewer juga mampu menampilkan kekuatan tautan kolaborasi penulisan artikel yang memiliki lebih dari 15 dokumen publikasi ilmiah adalah Bao, J dan Zhang, J. Visualisasi kerapatan serta visualisasi hamparan kekuatan tautan kata kunci mampu memberikan gambaran kecenderungan fokus penelitian bertema biorefineri biomassa berlignoselulosa yang telah dilakukan dari tahun 2000-2019.
\end{abstract}

Kata kunci: bibliometrik, biorefineri, lignoselulosa, VOSviewer, Scopus

\section{PENDAHULUAN}

Aspek keberlanjutan telah mendorong industri industri untuk mengembangkan sumber terbarukan guna produksi bahan bakar dan senyawa kimia. Terkait bahan baku, biomassa berlignoselulosa merupakan bahan baku yang sangat menjanjikan karena keberadaannya yang melimpah serta terbarukan.

Konsep biorefineri yang berkelanjutan diharapkan memenuhi kriteria kriteria seperti: (i) tidak menganggu ketahanan pangan, (ii) mampu menjaga regenerasi biomassa dan biodiversity, (iii) menimbulkan dampak terhadap lingkungan yang minimal, (iv) mampu beradaptasi dengan variasi kualitas biomass, (v) proses operasi yang fleksibel guna beradaptasi dengan permintaan pasar, (vi) melibatkan proses konversi dengan variasi bahan baku dan menghasilkan produk yang bervariasi (multiproduk) (Ozdenkci et al., 2017).

Pendekatan konversi kimia dan teknologi merupakan aspek yang krusial bagi performa tekno ekonomi proses biorefineri dalam menghasilkan berbagai produk turunan komponen-komponen berlignoselulosa.
Proses biorefineri biomassa berlignoselulosa dinyatakan dapat berpotensi menghasilkan selulosa, lignin, dan hemiselulosa berserta produk-produk turunan dari ketiga komponen utama lignoselulosa. Shokri dkk. (2013) menyatakan bahwa selulosa murni serta produk turunan selulosa yang diperoleh melalui reaksi etherifikasi dan esterifikasi memiliki berbagai fungsi dan telah diaplikasikan dalam bidang farmasetika. Methyl cellulose (MC), ethyl cellulose (EC), hydroxyethyl cellulose (HEC), hydroxypropyl cellulose (HPC), hydroxypropylmethyl cellulose (HPMC), carboxymethyl cellulose (CMC) dan sodium carboxymethyl cellulose (NaCMC) adalah beberapa contoh produk turunan selulosa yang diperoleh melalui reaksi etherifikasi.

Sementara itu cellulose acetate, cellulose acetate phthalate (CAP), cellulose acetate butyrate $(\mathrm{CAB})$, Cellulose acetate trimelitate (CAT), dan hydroxupropylmethyl cellulose phthalate (HPMCP) adalah produk-produk turunan dari selulosa yang diperoleh melalui reaksi estertifikasi (Shokri and Adibkia 2013). Chio dkk. (Chio et al. 2019) menyebutkan jika lignin melalui proses gasifikasi dapat 
menghasilkan syngas yang dapat dimanfaatkan sebagai sumber energi. Lignin juga dapat digunakan sebagai dispersan, aditif pada proses produksi polimer, aditif pada kain yang berfungsi sebagai penahan sinar UV serta sebagai nanopartikel lignin yang dapat digunakan pada proses penghantaran obat dan adsorbent logam berat (Chio et al. 2019). Sementara furfural dan xylite merupakan produk turunan hemiselulosa yang lebih lanjut dapat dikonversi menjadi berbagai produk kimia (Kamm 2004).

Keluasan spektrum potensi sumber bahan baku biomassa berlignoselulosa, keragaman jenis proses yang dapat diterapkan pada proses biorefineri biomassa berlignoselulosa, keragaman jenis proses konversi komponenkomponen utama biomassa berlignoselulosa serta keluasan potensi produk yang dihasilkan dari proses biorefineri biomassa berlignoselulosa telah mendorong berkembangnya penelitian dan publikasi bertema biorefineri lignoselulosa.

Analisa bibliometrik publikasi ilmiah berkaitan dengan tema riset merupakan salah satu komponen penting dalam suatu proses riset. Analisa terhadap publikasi ilmiah merupakan tool yang berguna untuk menganalisa proses pembangkitan dan evolusi pengetahuan, serta memberikan manfaat dalam mengevaluasi kualitas keilmuan serta dampaknya terhadap dunia akademis (Capobianco-uriarte et al. 2019). Analisa bibliometrik juga dapat digunakan untuk menganalisa kecenderungan arah penelitian dan publikasi yang telah dilakukan, tengah dilakukan dan potensi kedepan. Dalam publikasi ini disajikan hasil analisa bibliometrik publikasi ilmiah dengan topic biorefineri biomassa berlignoselulosa yang diterbitkan pada berbagai jurnal yang terindeks scopus pada tahun 2000-2019.

\section{METODOLOGI}

Publikasi ilmiah yang dipublikasikan dari tahun 2000-2019 diunduh dari database Scopus yang diakses pada 9 Mei 2020 dengan menggunakan kata kunci "biorefineri dan lignocellulose". Pencarian dengan kata kunci tersebut dibatasi pada judul, abstrak dan kata kunci. Tipe dokumen dibatasi untuk "article or review". Data yang diperoleh selanjutnya dianalisa menggunakan metode bibliometrik menggunakan program VOSviewer 1.6.15. Analisa bibliometrik dilakukan menggunakan
VOSviewer untuk menganalisa kepenulisan bersama (co-authorship) berdasarkan nama penulis dan afiliasi penulis, serta analisa kemunculan (co-occurrence) berdasar kata kunci. Hasil analisa bibliometrik ditampilkan menggunakan visualisasi jaringan, hamparan dan kerapatan. Visualisasi hasil disajikan berdasar nilai kekuatan tautan (total link strength).

\section{HASIL DAN PEMBAHASAN}

Hasil penelusuran menunjukkan jika publikasi ilmiah yang memuat kata kunci "biorefineri dan lignocellulose" pada judul, abstrak dan atau kata kunci dari tahun 20002006 di database scopus ditemukan sebanyak 732 buah dokumen dengan distribusi 568 merupakan publikasi ilmiah berkategori artikel sementara 164 merupakan publikasi ilmiah berkategori review. Publikasi ilmiah dengan kata kunci "biorefineri dan lignocellulose" pada judul, abstrak dan atau kata kunci mulai muncul pada tahun 2006 dengan hasil temuan sebanyak 4 dokumen.

Ketiadaan temuan publikasi ilmiah dengan istilah "biorefinery dan lignocellulose" pada judul, abstrak dan atau kata kunci pada sebelum tahun 2006 dapat disebabkan masih kurangnya kesadaran akademisi akan istilah biorefineri. Wenger dan Stern (2021) melakukan kajian literature sistematik dengan fokus terhadap bahan baku proses biorefinery menggunakan database yang bersumber dari scopus.

Hasil kajian Wenger dan Stern (2021) menunjukkan jika publikasi ilmiah dengan kata kunci "biorefinery feedstocks" sebelum tahun 2006 ditemukan dalam jumlah yang minim serta menyatakan bahwa kurangnya kesadaran (the lack of awareness) dari dunia akademis maupun industri sebagai penyebabnya (Wenger and Stern 2021). Jumlah publikasi ilmiah dengan kata kunci "biorefineri dan lignocellulose" selanjutnya mulai meningkat (Gambar 1), dengan peningkatan yang cukup signifikan terjadi antara tahun 2014 ke tahun 2016, dimana peningkatan mencapai $83,01 \%$. Hal tersebut dapat dikorelasikan dengan peningkatan kesadaran berbagai pihak akan arti penting dan potensi proses biorefineri bagi pemenuhan berbagai produk turunan dari proses biorefineri, dimana salah satunya adalah biofuel.

Valdivia dkk. (2016) menyebutkan jika kebutuhan akan biofuels mengalami peningkatan yang cukup signifikan antara tahun 
2014-2016 dimana menurut EPA, kebutuhan akan biofuel yang berasal dari selulosa pada tahun 2014, 2015 dan 2016 adalah berturutturut sebesar 33, 123 dan 230 juta gallon (Valdivia and Galan 2020).

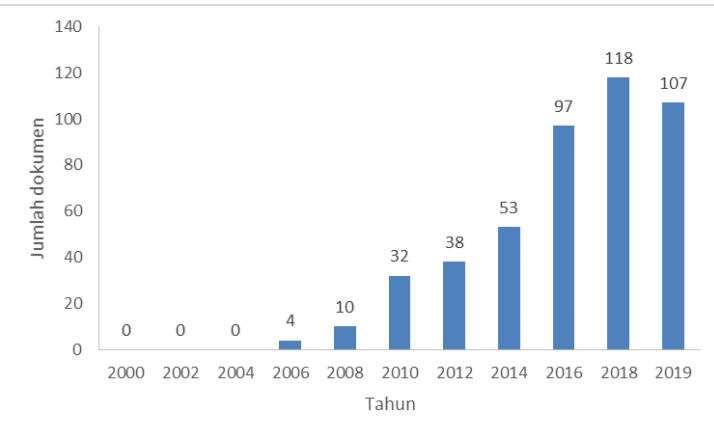

Gambar 1. Jumlah publikasi ilmiah dengan istilah "biorefinery dan lignocellulose" pada judul, abstrak dan atau kata kunci (20002019; database: scopus; $n=732$ ).

Hasil pengunduhan data publikasi ilmiah dengan kata kunci pencarian "biorefinery dan lignocellulose" pada judul, abstrak dan atau kata kunci yang dipublikasikan dari 2000-2019 di database scopus menunjukkan jika China, Amerika, Jerman, Kanada dan Spanyol adalah 5 negara teratas dari afiliasi penulis pertama (Gambar 2.a) dengan jumlah dokumen untuk masing-masing 5 negara teratas sebanyak 157 , 147, 54,53 dan 43, berturut-turut.

Analisa bibliometrik co-authorship yang menggambarkan kolaborasi antar penulis berdasar asal negara dilakukan dengan menggunakan VOSviewer. Visualisasi hasil analisa menggunakan VOSviewer dapat ditampilkan melalui 3 jenis pilihan tampilan yang terdiri atas visualisasi jaringan (network visualization), visualisasi hamparan (overlay visualization), dan visualisasi kerapatan (density visualization). Apabila kekuatan tautan atau jumlah dokumen dari jejaring diinginkan untuk divisualisasikan maka network visualization adalah jenis visualisasi yang dapat dipilih pada menu tampilan hasil analisa menggunakan VOSviewer.

Visualisasi hasil analisa bibliografi yang memperlihatkan jejak history penelitian dapat diperoleh apabila kita memilih menu tampilan overlay visualization, sedangkan density visualization mempelihatkan kerapatan/ penekanan pada unit yang dianalisa.

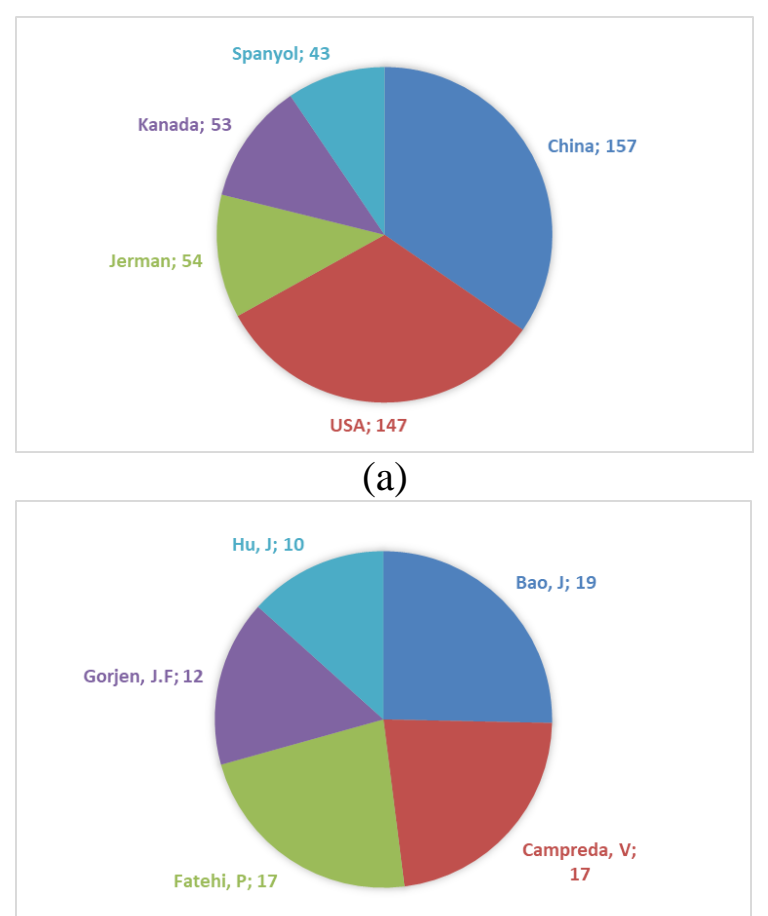

(b)

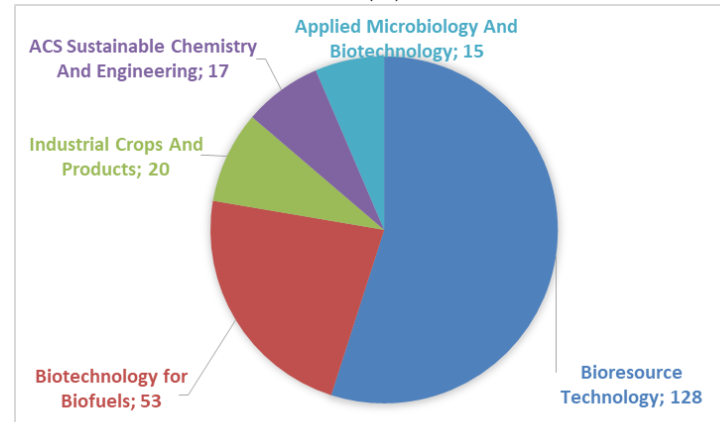

(c)

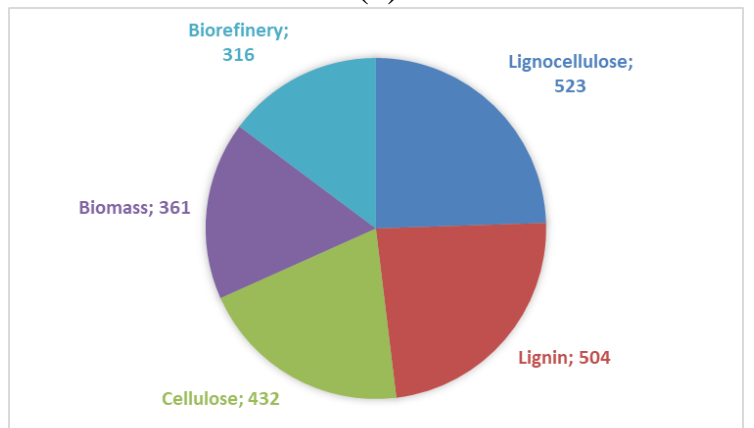

(d)

Gambar 2. Daftar urutan lima teratas: a. Negara dari afiliasi penulis pertama, $b$ jurnal/sumber dokumen, $c$ penulis pertama, dan d kata kunci pada publikasi ilmiah dengan topic "biorefinery dan lignocellulose" dari tahun 2000-2019 (20002019; database: scopus, $n=732$ )

Kekuatan tautan kolaborasi antar penulis berdasar asal negara pada publikasi ilmiah yang 
memiliki istilah "biorefinery dan lignocellulose" pada judul, abstrak dan atau kata kunci hasil dari analisa menggunakan VOSviewer dengan jumlah minimum dokumen 20 dan 30 dari hasil analisa bibliometrik ditampilkan dengan pilihan tampilan visualisasi jaringan (network visualization) (Gambar 3a dan 3b). Gambar 3a dan 3b memperlihatkan bahwa tampilan hasil analisa kolaborasi antar penulis berdasar asal negara tersaji dalam 3 dan 2 kelompok warna, dimana masing masing warna tersebut mewakili satu cluster.

Semakin banyak jumlah minimum dokumen yang ditetapkan dalam proses analisa bibliometrik maka jumlah cluster yang diperoleh akan semakin kecil. Gambar 3a dan $3 \mathrm{~b}$ memperlihatkan bahwa nodul yang mewakili China dan Amerika memiliki ukuran yang jauh lebih besar bila dibandingkan dengan nodul yang mewakili nama-nama negara lainnya. Hal tersebut menunjukkan jika kolaborasi penulis dalam mempublikasikan hasil riset terkait tema biorefineri biomassa berlignoselulosa yang berafiliasi dari negara China dan Amerika lebih kuat dibandingkan kolaborasi antar penulis yang berafiliasi dari negara-negara lain.

Wang dkk. (2013) melakukan kajian bibliometric untuk menganalisa kekuatan kolaborasi internasional publikasi ilmiah oleh penulis yang berafiliasi dari negara China dengan penulis dari negara lain berdasar data dari Web of Science. Hasil penelitian mereka menunjukkan jika 95\% kolaborasi internasional publikasi ilmiah penulis yang berafiliasi dari China yang ditulis bersama dengan penulis dari 20 negara lain, dengan $42.25 \%$ diantaranya ditulis bersama dengan penulis yang berafiliasi dari negara Amerika (Wang et al. 2013).

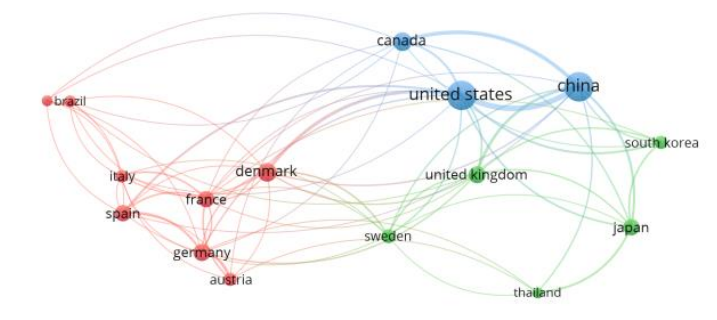

B vosviewer

(a)

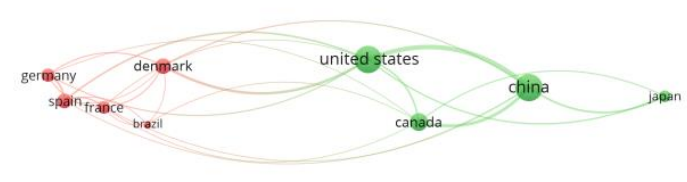

\& vosviewer

(b)

Gambar 3. Visualisasi jejaring kekuatan tautan kolaborasi antar penulis berdasar asal negara pada publikasi ilmiah yang memiliki istilah "biorefinery dan lignocellulose" pada judul, abstrak dan atau kata kunci (2000-2019; database: scopus; $\mathbf{n}=$ 732) hasil dari analisa menggunakan VOSviewer dengan jumlah minimum dokumen: (a) 20 dan (b) 30.

Hasil pencarian dokumen publikasi ilmiah dengan kata kunci pencarian "biorefinery dan lignocellulose" pada judul, abstrak dan atau kata kunci yang dipublikasikan dari 2000-2019 di database scopus menunjukkan jika 5 penulis yang memiliki jumlah publikasi terbanyak disajikan pada Gambar 2b. Kelima penulis tersebut berafiliasi dari negara China (Bao, J), Thailand (Campreda, V), Kanada (Fatehi, P dan $\mathrm{Hu}, \mathrm{J}$ ), serta Afrika Selatan (Gorjens, J.F).

Analisa bibliometerik menggunakan VOSviewer dapat memberikan informasi mengenai hubungan jejaring kolaborasi penulisan publikasi ilmiah melalui menu tipe analisa "co-authorship" dan unit analisa "author". Visualisasi jejaring kekuatan tautan kolaborasi antar penulis berdasar nama penulis untuk publikasi ilmiah dengan istilah "biorefinery dan lignocellulose" pada judul, abstrak dan atau kata kunci yang dipublikasikan pada jurnal terindeks scopus dari tahun 20002019 dengan jumlah minimum dokumen sebanyak 10 dan 15 disajikan pada Gambar 4.

Gambar 4 menunjukkan jika Campreda, V dan Fatehi, $P$ tidak muncul di visualisasi jejaring kolaborasi antar penulis berdasar nama penulis untuk publikasi ilmiah dengan istilah "biorefinery dan lignocellulose" pada judul, abstrak dan atau kata kunci yang dipublikasikan pada jurnal terindeks scopus dari tahun 20002019 dengan jumlah minimum dokumen sebanyak 10 (Gambar 4a). Hal tersebut dikarenakan kedua penulis tersebut memiliki 
jumlah dokumen publikasi ilmiah dengan istilah "biorefinery dan lignocellulose" pada judul, abstrak dan atau kata kunci lebih dari 10 dokumen namun demikian kekuatan link-nya rendah.

Hal tersebut didukung oleh visualisasi yang dihasilkan dari jejaring kolaborasi antar penulis berdasar nama penulis untuk publikasi ilmiah dengan istilah "biorefinery dan lignocellulose" pada judul, abstrak dan atau kata kunci yang dipublikasikan pada jurnal terindeks scopus dari tahun 2000-2019 dengan jumlah minimum dokumen sebanyak 15 (Gambar 4b), dimana ada 4 penulis yang memenuhi persyaratan (memiliki lebih dari 15 dokumen), dan tidak ada garis yang menghubungkan antara kedua penulis (Campreda, V dan Fatehi, P) dengan dua orang penulis lainnya (Bao, J dan Zhang, $\mathrm{J})$.

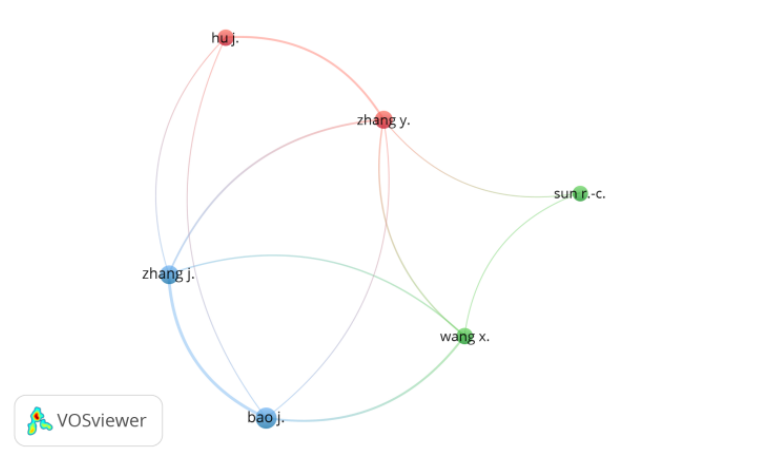

(a)

\& Vosviewer champreda v.

(b)

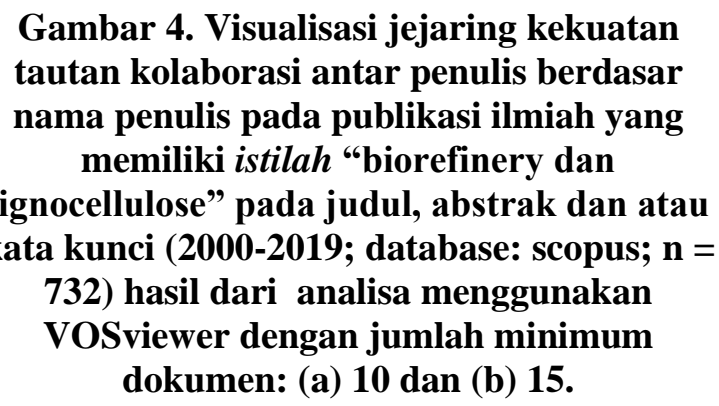

Gambar 4. Visualisasi jejaring kekuatan tautan kolaborasi antar penulis berdasar memiliki istilah "biorefinery dan lignocellulose" pada judul, abstrak dan atau kata kunci (2000-2019; database: scopus; $\mathbf{n}=$ 732) hasil dari analisa menggunakan dokumen: (a) 10 dan (b) 15.
Selanjutnya, Gambar 2c menunjukkan 5 jurnal teratas yang menjadi sumber (source) dari publikasi ilmiah dengan kata kunci pencarian "biorefinery dan lignocellulose" pada judul, abstrak dan atau kata kunci yang dipublikasikan dari 2000-2019. Bioresource technology merupakan jurnal yang memuat dokumen terbanyak dan menjadi pilihan utama periset dan penulis yang mempublikasikan hasil penelitian maupun artikel berjenis review dengan topic biorefinery dan lignocellulose.

Biomassa berlignoselulosa merupakan salah satu bahan yang masuk dalam kategori sumber bahan hayati (bioresource), sementara biorefineri konsep proses pengolahan sumbersumber hayati yang dianalogikan dengan fraksinasi petroleum (Wenger and Stern 2021). Biotechnology for Biofuels merupakan jurnal yang menempati urutan kedua yang menerbitkan publikasi ilmiah dengan kata kunci pencarian "biorefinery dan lignocellulose" pada judul, abstrak dan atau kata kunci yang dipublikasikan dari 2000-2019. Hal tersebut memperlihatkan bahwa arah penelitian biorefineri biomassa berlignoselulosa banyak diarahan pada proses produksi biofuel.

Balan (2014) menyatakan bahwa produksi biofuel dan biochemical menggunakan biomassa berlignoselulosa memiliki beberapa keunggulan seperti (i) menggunakan bahan terbarukan dan berkelanjutan, (ii) secara tidak langsung membantu fiksasi karbon dioksida (gas rumah kaca yang menyebabkan pemanasan global), (iii) memfasilitasi dan menstimulasi perkembangan ekonomi lokal, (iv) menurunkan polusi udara akibat pembakaran dan pembusukan biomassa di areal pertanian, dan (v) meningkatkan ketahanan energi negara yang bergantung pada impor minyak (Balan 2014).

Hasil pencarian dokumen publikasi ilmiah dengan kata kunci pencarian "biorefinery dan lignocellulose" pada judul, abstrak dan atau kata kunci yang dipublikasikan pada jurnal terindeks scopus dari 2000-2019 juga menghasilkan data berupa daftar kata kunci lengkap dengan frekuensi kemunculannya. Selulosa, lignin, lignoselulosa, biomassa dan biorefineri, berturut-turut merupakan lima kata kunci yang mendominasi publikasi ilmiah dengan kata kunci pencarian "biorefinery dan lignocellulose" pada judul, abstrak dan atau kata kunci yang dipublikasikan pada jurnal terindeks scopus dari 2000-2019 (Gambar 2d).

Selulosa dan lignin menempati urutan pertama dan kedua kata kunci yang sering 
muncul atau digunakan oleh para penulis. Hal tersebut menunjukkan bahwa proses biorefineri menitikberatkan pada isolasi dan atau proses konversi lanjutan dari kedua komponen utama biomassa berlignoselulosa.

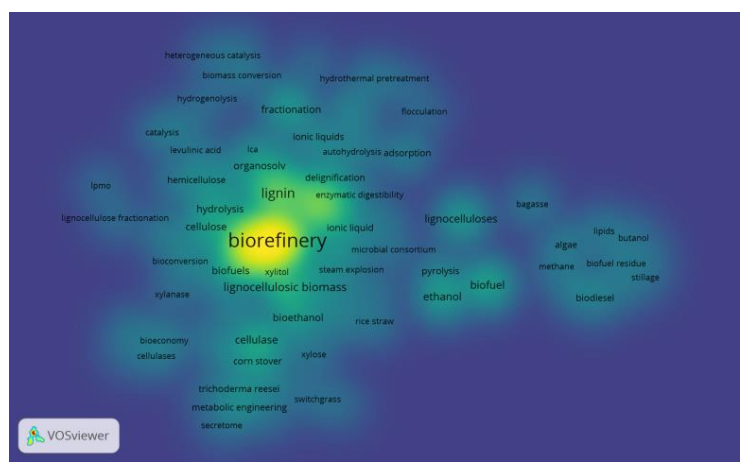

(a)

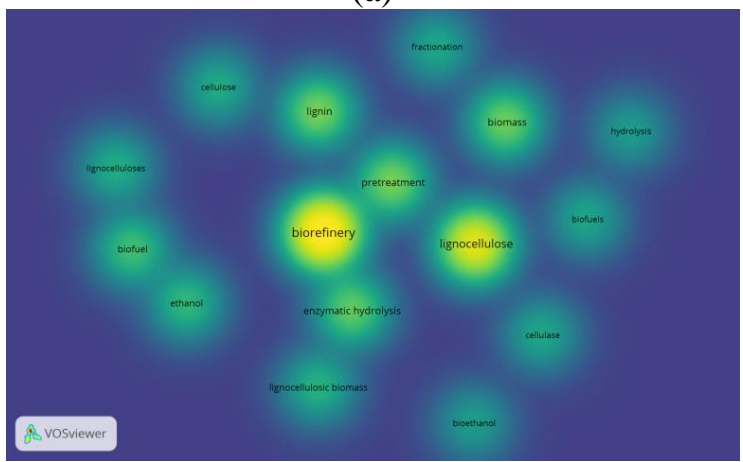

(b)

Gambar 5. Visualisasi kerapatan kekuatan tautan untuk kata kunci pada publikasi ilmiah yang memiliki istilah" "biorefinery dan lignocellulose" pada judul, abstrak dan atau kata kunci (2000-2019; database: scopus; $\mathbf{n}=$ 732) hasil dari analisa menggunakan VOSviewer dengan jumlah minimum dokumen: (a) 5 dan (b) 20.

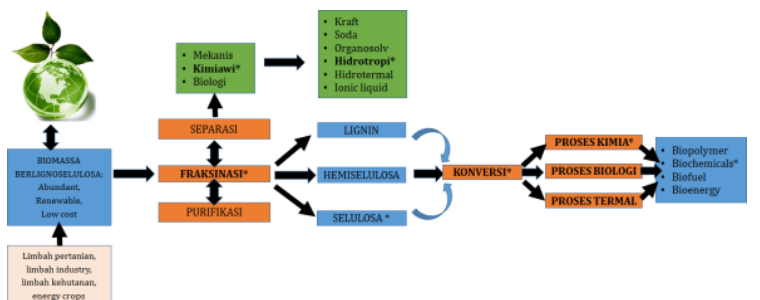

Gambar 6. Skema tahapan konversi biomassa pada proses refinery

Analisa bibliometrik menggunakan VOSviewer dengan tipe analisis "cooccurrence" dengan unit analisis "author keywords" dan pilihan tampilan visualisasi hasil "density visualization" dan kekuatan tautan yang dibatasi untuk jumlah minimum kemunculan kata kunci sebanyak 5 dan 20 disajikan pada Gambar 5a dan 5b. Gambar 5a dan 5b menunjukkan jika biorefineri dan lignoselulosa memiliki nilai kekuatan tautan yang lebih besar dari kata kunci lainnya. Kata kunci "pretreatment, fractionation dan hydrolysis" juga muncul di Gambar 5 b.

Hal tersebut menunjukkan jika teknologi proses fraksinasi dan konversi komponenkomponen biomassa berlignoselulosa merupakan point-point penting yang telah, sedang dan masih perlu dikaji terkait dengan proses biorefineri biomassa berlignoselulosa sebagaimana skema tahapan proses konversi biomassa pada proses biorefineri yang disajikan pada Gambar 6. Kumar dkk. (2020) menyatakan jika pretreatment yang pada dasarnya adalah suatu proses fraksinasi komponen-komponen utama biomassa berlignoselulosa adalah salah satu tahap penting dalam proses konversi biomassa berlignoselulosa yang efisien guna lebih lanjut dapat diikuti dengan proses konversinya menjadi biofuel dan bio-based product lainnya.

Pemilihan proses pretreatment sangat mempengaruhi biaya produksi secara keseluruhan serta konfigurasi bahan baku proses biorefineri berbasis biomassa berlignoselulosa (Kumar et al. 2020).

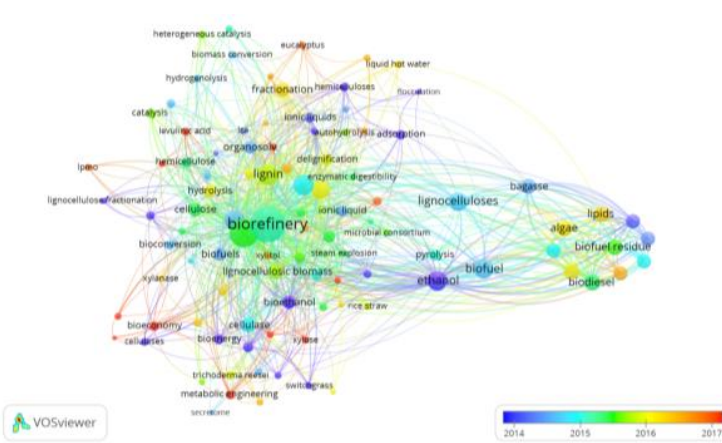

Gambar 7. Visualisasi hamparan kekuatan tautan kata kunci pada publikasi ilmiah dengan istilah "biorefinery dan

lignocellulose" pada judul, abstrak dan atau kata kunci (2000-2019; database: scopus; $\mathbf{n}=$ 732) hasil analisa menggunakan VOSviewer dengan jumlah minimum dokumen 5.

Gambar 7 merupakan visualisasi hamparan kekuatan tautan kata kunci pada publikasi ilmiah dari 2000-2019 yang memuat istilah "biorefinery dan lignocellulose" pada judul, abstrak dan atau kata kunci yang ditemukan pada database scopus dan dianalisa menggunakan VOSviewer dengan jumlah minimum 5 dokumen. Gambar 7 memperlihatkan bahwa riset dan publikasi 
dalam bidang biorefineri biomassa berlignoselulosa mulai mengarah kepada penggunaan enzim, rekayasa metabolit, analisa bioekonomi, penggunaan LPMO (Lytic polysaccharide monooxygenases) pada proses biorefineri.

Hal tersebut didasarkan pada hasil visualisasi hamparan yang memperlihatkan nodul-nodul berwarna merah dan oranye yang merepresentasikan tahun-tahun terkini diterbitkannya publikasi ilmiah yang memuat kata-kata kunci antara lain "metabolic engineering, bioeconomy, LPMO, cellulose, levulinic acid dan xylose. Lytic polysaccharide monooxygenases merupakan enzim yang dewasa ini mendapat perhatian dari periset karena enzim ini mampu bersinergi dengan selulase dan kitinase serta menunjukkan kemampuan yang baik dalam meningkatkan aktivitas campuran enzim pendegradasi biomass (Escamilla-alvarado et al. 2017).

Lebih lanjut, Baritugo dkk. (2018) menyatakan bahwa riset-riset mengenai rekayasa genetik saat ini banyak dikembangkan guna meningkatkan serapan substrat alami seperti glukosa, fructosa, maltosa, mannosa, ribose dan sucrosa, yang oleh karenanya akan meningkatkan yield produksi bahan bahan kimia berbasis komponen biomassa berlignoselulosa.

\section{KESIMPULAN}

Terdapat 732 buah publikasi ilmiah yang memuat kata kunci "biorefineri dan lignocellulose" pada judul, abstrak dan atau kata kunci dari tahun 2000-2006 di database scopus dengan $77.6 \%$ diantaranya berupa publikasi ilmiah artikel serta $22.4 \%$ publikasi ilmiah berkategori review. Hasil pencarian di database scopus menunjukkan jika Bioresource technology merupakan jurnal yang memuat dokumen terbanyak dan menjadi pilihan utama periset dan penulis yang mempublikasikan hasil penelitian maupun artikel berjenis review dengan topic biorefinery dan lignocellulose.

Analisa bibliometrik menggunakan VOSviewer menunjukkan jika kolaborasi penulis dalam mempublikasikan hasil riset terkait tema biorefineri biomassa berlignoselulosa yang berafiliasi dari negara China dan Amerika lebih kuat dibandingkan kolaborasi antar penulis yang berafiliasi dari negara-negara lain. Hasil analisa bibliometri menggunakan VOSviewer juga mampu menampilkan kekuatan tautan kolaborasi penulisan publikasi ilmiah. Visualisasi kerapatan serta visualisasi hamparan kekuatan tautan kata kunci mampu memberikan gambaran kecenderungan fokus penelitian bertema biorefineri biomassa berlignoselulosa yang telah dilakukan dari tahun 2000-2019.

Arah penelitian biorefineri biomassa berlignoselulosa banyak diarahkan pada proses produksi biofuel, serta menitikberatkan pada isolasi dan atau proses konversi lanjutan dari kedua komponen utama biomassa berlignoselulosa. Riset dan publikasi dalam bidang biorefineri biomassa berlignoselulosa mulai mengarah kepada proses-prosee enzimatis, rekayasa genetik serta analisa bioekonomi.

\section{DAFTAR PUSTAKA}

Balan V. 2014. Current Challenges in Commercially Producing Biofuels from Lignocellulosic Biomass.

Capobianco-uriarte $\mathrm{M}$, Casado-belmonte $\mathrm{P}$, Mar G, Ter E. 2019. A Bibliometric Analysis of International. doi: 10.3390/su11071877

Chio C, Sain M, Qin W. 2019. Lignin utilization: A review of lignin depolymerization from various aspects. Renew. Sustain. Energy Rev.

Escamilla-alvarado C, Pérez-pimienta JA, Ponce-noyola T. 2017. An overview of the enzyme potential in bioenergy-producing biorefineries. doi: 10.1002/jctb.5088

Kamm MB. 2004. Principles of biorefineries. 137-145. doi: 10.1007/s00253-003-1537-7

Kumar B, Bhardwaj N, Agrawal K. 2020. Current perspective on pretreatment technologies using lignocellulosic biomass: An emerging biorefinery concept. $199 . \quad$ doi: 10.1016/j.fuproc.2019.106244

Shokri J, Adibkia K. 2013. Application of Cellulose and Cellulose Derivatives in Pharmaceutical Industries

Valdivia M, Galan JL. 2020. Opinion Biofuels 2020: Biorefineries based on lignocellulosic materials. doi: 10.1111/1751-7915.12387

Wang X, Xu S, Wang Z. 2013. International Scientific Collaboration of China: Collaborating Countries, Institutions and Individuals. 1-11. doi: 10.1007/s11192012-0877-4

Wenger J, Stern T. 2021. Reflection on the research on and implementation of 
biorefinery systems - a systematic literature review with a focus on feedstock. 1-18. doi: 10.1002/bbb.2021 